\title{
K některým filosofickým aspektům Dantova díla ${ }^{1}$
}

\section{On some philosophical aspects of Dante's work}

\author{
Pavel Floss \\ Filozofická fakulta \\ Univerzity Palackého v Olomouci \\ Kř́̌žkovského 10, 77180 Olomouc \\ \& \\ Filozofická fakulta \\ Univerzita Hradec Králové \\ Rokitanského 62, 50003 Hradec Králové \\ paflos@centrum.cz
}

\begin{abstract}
Abstrakt/Abstract
Článek se zaměřuje na některé aspekty Dantova spisu De monarchia, především na povahu Alighieriho realizace ideje celosvětové monarchie, jež je jedinou zárukou trvalého míru, který je představen jako nezbytný předpoklad plné realizace všech duchovních potencí lidského rodu jako takového. Ačkoliv Dantovy názory vykazují ovlivnění dobovým averroismem, opírá se ve filosofické argumentaci pro upřednostnění vlády jediného celosvětového vladaře o scholasticky interpretovanou aristotelskou metafyziku. Autor konfrontuje základní momenty Dantovy politické filosofie s názory Marsilia z Padovy a především s koncepcemi Tomáše Akvinského. Ačkoliv Dante přispěl k posílení autonomie světského a vymanění se panovnické moci z nároků, jež si osobovalo dobové papežství, vytvořilo jeho zbožštění panovnické moci ideové předpoklady pro zbožštění státu a novodobý etatismus.
\end{abstract}

The study focuses on aspects of Dante`s De monarchia — particularly on Alighieri`s conception of realization of the idea of universal monarchy as the only guarantee of permanent peace. This is presented as a necessary precondition for a full realization of all spiritual potentialities of the human kind as such. Although Dante's views display an influence of contemporary Averroism, his philosophical argumentation in favour of the rule of one universal monarch is based on scholastic interpretations of Aristotelian metaphysics. Key moments of Dante`s philosophy are confronted with the views of Marsilius of Padua

1 Tato studie je výsledkem badatelské činnosti podporované Grantovou agenturou České republiky v rámci grantu GA ČR 14-37038G „Mezi renesancí a barokem: Filosofie a vědění v českých zemích a jejich širší evropský kontext“. 
and, particularly, with the conceptions of Thomas Aquinas. It is then argued that Dante contributed to strengthening of the autonomy of the secular order and to liberation of monarchic rule from power claims of the contemporary papacy. At the same time, however, his deification of monarchic rule created preconditions for deification of the state and modern etatism.

Dante je vzdělané veřejnosti znám především jako jeden z největších básníků, jehož Divina commedia patří k trvalým skvostům světové literatury. Alighieri však napsal též řadu filosofických traktátů, jež zaujímají nikoliv nevýznamné místo v dějinách evropského filosofického myšlení. V tomto kontextu obrátil bych pozornost $\mathrm{k}$ onomu jeho textu, který je příspěvkem k dějinám evropské politické filosofie, totiž $\mathrm{k} D e$ monarchia. ${ }^{2} \mathrm{~K}$ dalším spisům s filosofickou problematikou se řadí i některé jeho další texty, např́iklad rozsáhlejší práce nazvaná Convivio (1304-1307), panorámující dobové vědění, ale i úvahy týkající se např́klad Božské komedie ve formě dopisu Cangrandovi della Scala (1317) a též spis $O$ rodném jazyce (De vulgari eloquentia; dokončená část spisu pochází z let 1302-1305). Mezi Dantovými filosofickými díly zaujímá pak specifické postavení Quaestio de terra et aqua (1320).

Jak hlásá již název, zabývá se Alighieri v tomto spisku (který je písemnou dokumentací prezentace, realizované ve Veroně v roce 1320) dvěma ze čtyř elementů, jež byly v duchu aristotelské filosofie považovány za prvky těžké, zatímco vzduch a oheň byly označovány jako elementy lehké. V aristotelské fyzice měly všechny elementy podle své povahy (přirozenosti) stanovena svá „místa“, přičemž kolem středu celého univerza se v nejnižší kruhové vrstvě měla nalézat země, nad ní voda, pak vzduch a vrchní část tzv. sublunární sféry zaujímal oheň. Od Měsíce až po tzv. osmé nebe, $v$ němž se nacházely hvězdy, se rozprostírala superlunární část vesmíru, jež nebyla komponována ze živlů, ale z látky dokonalejší, totiž z éteru.

Dante problematizuje ve svém textu obecně sdílené přesvědčení, že prvek země leží níže než prvek voda. ${ }^{3}$ Probírá ve spisku argumenty pro tradiční rozmístění prvků a ukazuje přitom na rozpory, do nichž se mnozí filosofové při své kosmologické argumentaci dostávají. Prezentuje názory některých antických a středověkých autorů, např́íklad Aristotela, Ptolemaia, Augustinova žáka Pavla Orosia a Averroa. Při řešení daného problému konfrontuje nejen výroky různých filosofických autorit, nýbrž pracuje i s analýzou pozorování univerzitně neučených, ale zkušených osob, např́íklad se zprávami mořeplavců a zohledňuje i různé výroky Bible. Quaestio de terra et aqua

\footnotetext{
${ }^{2} \mathrm{~K}$ této problematice viz: I. Müller (2011).

Z bohaté zahraniční literatury bych odkázal především na následující práce: Passerin d'Entrèves (1952); Di Scipio (1983); Farnell (1985); Ferrante (1994); Reynolds (2006); Cassell (2004); Gorni (2008).

${ }^{3}$ Dante $(1960,17$ (IX)).
} 
poskytuje námět pro zkoumání vztahu filosofických a teologických momentů tehdejšího myšlení a právě těmi bych se chtěl zabývat v některé ze svých dalších studií.

Vrátím-li se nyní ještě na chvíli k Dantovu básnickému veledílu, pak lze konstatovat, že tento epos je po obsahové stránce uměleckým obrazem architektury středověkého řádu stvořeného univerza, ${ }^{4}$ ale co se týká aspektů psychologických a formálních, ohlašuje se v něm již individualismus humanismu a renesance, spolu s jeho autoretrospektivními tendencemi a smyslem pro lidskou afektivitu. ${ }^{5}$ Pro povahu ideového poselství díla je signifikantní, že mezi starověkými mysliteli je jakožto vůdčí osobnost představen Aristotelés a středověkým filosofickým nebem Danta provádí Tomáš Akvinský, což napovídá aristotelsko-tomistickou intenci Dantova myšlení, patrnou i v jeho filosofických textech. ${ }^{6}$

Závěrem úvodní pasáže této studie chtěl bych však ještě poukázat alespoň na skutečnost, že v Božské komedii dopracovává se Dante až k jakési apoteóze svobody lidského rozhodování, kterou ve spise De monarchia nenacházíme. V De monarchia je opravdová svoboda rozhodování mezi všemi lidmi připsána jen vladaři světové říše. V Božské komedii je však lidská svoboda pojata jako hrdinský zápas lidských jedinců, vzdorujících moci působení sil a vlivů superlunární sféry na dění ve sférée sublunární. Touha po svobodném rozhodování, která je v Divina commedia přirovnána k ohni, který není možno žádným způsobem zadusit. ${ }^{7}$ Dantův étos svobody působil patrně na další

\footnotetext{
${ }^{4} \mathrm{Na}$ tomto místě bych poukázal na některé formulace, jež se v prvním dílu Cest evropského myšlení týkají jednoho z největších středověkých filosofů - Tomáše Akvinského: „Svou noetickou koncepci buduje Tomáš na základě své vize hierarchicky strukturovaného řádu jsoucího, který má výraznou antropologickou komponentu.“; Floss (2004, s. 243). „... univerzum nebylo stvořeno pro Boží dobrotivost nebo závazek plynoucí z této dobrotivosti, nýbrž ... stvoření univerza se událo podle řádu moudrosti ... Zdůvodnění stvořeného řádem moudrosti emancipuje mnohost a rozmanitost z ontologické nedokonalosti, do níž byly dosud...ponořeny.“ (Floss 2004, s. 239-240)

V tomto kontextu bych též zdůraznil, že jsem kritický vůči současné tendenci výkladu Dantovy filosofie, $v$ níž se přehnaně akcentuje vliv dobového averroismu na utváření jeho myšlení.

5 Středověká je i Dantova představa o hranicích lidmi obývaného světa, který tvořil tř̌i kontinenty: Evropu, Afriku a Asii. Zatímco pro vrcholnou renesanci bylo charakteristické nadšené objevování nových pevnin a ostrovů, píše Dante až s jakýmsi zadostiučiněním, že již Odysseovi přineslo jeho rozhodnutí plout za sloupy Herkulovy (šlo o prostory na západ od Gibraltarské úžiny) záhubu; Dante (2007, s. 133-134).

${ }^{6}$ Jestliže se dnes můžeme setkat s názorem, že politická teorie spisu De monarchia je antipapalistická a antitomistická, pak lze bez výhrad souhlasit jen stvrzením prvním. Skutečnost, že Alighieri byl antipapalistou, ještě neznamená, že se eo ipso zřekl všeho, co bylo typické pro tomistický proud středověkého myšlení. Je ovšem pravda, že mezi Tomášovou a Dantovou koncepcí státu a vztahu moci světské a duchovní jsou určité zásadní rozdíly, na druhé straně však nelze přehlédnout to, co mají díky svým aristotelským základům společného.

${ }^{7}$ Dante (1966-1967, s. 76-81): „Che volontà, se non vuol, non s'ammorza,/ ma fa come natura face in foco,/ se mille volte violenza il torza;/ Per che, s'ella si piega assai a poco 'y / segue la forza; e cosi queste fero,/ possendo ritornare al santo loco.“; „Nebot' když nechce, vůle nezhasíná, / však je jak oheň přirozenost čistá, / jenž stokrát sražen do výše se vzpíná. / At'
} 
humanisty, jak dokládají oslavná slova na Danta v Salutatiho spisu De fato, fortuna et casu. $^{8}$

Ačkoliv hlavním dílem politické filosofie čtrnáctého století je spis Defensor pacis Marsilia z Padovy, jenž u historiků politického myšlení vzbuzuje mnohem větší respekt než Dantova kniha De monarchia (v níž někteří autoři nacházejí simplifikující či blasfemické výroky či nedostatečnou konciznost výkladu), lze oba texty prezentovat jako exempla dvou různých přístupů $\mathrm{k}$ řešení dobových společenských a ideových zápasů, jež vznikaly zhruba ve stejné době (Marsilio začíná koncipovat své dílo jen několik let poté, co Dante dokončil spis De monarchia). Zásadní rozdíl mezi oběma spisy spočíval v tom, že Dantova De monarchia byla projektem vybudování jediného celosvětového království s jediným vládcem v jeho čele, zatímco Defensor pacis byl patrně nejrevolučnějším politickým dílem konce středověku, kumulujícím řadu konceptů, jež dále rozvíjeny, vytvářely předpoklady pro vznik ideje a realizaci demokratického zřízení $\mathrm{v}$ časech pozdního novověku a počínající moderny. Mám na mysli především Marsiliův požadavek oddělení zákonodárné a exekutivní moci, nebot' na tvorbě zákonů se jako první a jediná účinná přričina má podílet obec občanů („,civium universitas“"), respektive její prevalentní část. ${ }^{9}$ Znamenalo to, že z této aktivity byli vyloučeni provinilci, služebnictvo, ženy a chlapci, kteři ještě nedospěli v muže. ${ }^{10}$ Významný byl též Marsiliův požadavek zrušení privilegovaného postavení církve a kléru a rozsáhlé návrhy na demokratizaci církve. Pro fungování všech úřadů byl relevantní Marsiliův požadavek jejich volitelnosti, nebot' volba je jediný způsob, jak lze zabezpečit jednoduché a dobré zrrízení jakéhokoliv úřadu. V souvislosti s tím velmi ostře kritizuje odpor církevní hierarchie vůči institutu volby vůbec, nebot' jejím odmítáním se korumpuje církevní společenství všech věřících („universa fidelium multitudo“), jež jediné by mělo být aktérem volby. ${ }^{11}$

Marsiliův spis vzbudil po svém dokončení brzy velký zájem, který ho provázel po několik století. Ačkoliv byl spis spolu s texty Viklefovými odsouzen papežem Řehořem XI. roku 1378 a ačkoliv byl stíhán dalšími papežskými zákazy, těšil se až do osmnáctého století značnému zájmu. Koloval nejprve v rukopisech, posléze byl vydáván tiskem (ovšem poprvé patrně až v roce 1515) a - což je pro jeho působení zvlášt' důležité - byl přeložen do hlavních evropských jazyků. Italský překlad byl pořízen ve Florencii již v roce 1363 a ve Francii koloval anonymní překlad spisu (po jehož autorovi pátrala kurie) v dvorském prostředí v sedmdesátých letech čtrnáctého století. V roce 1535 přeložil spis do angličtiny $\mathrm{W}$. Marschall a vydání financoval

sebemín̆ se vzdává, dozajista / jde s násilím, jak věc / zde těch se měla, / když navrátit se mohly v svatá místa.“; česky: Božská komedie (1952, s. 395).

${ }^{8}$ Salutati (1985).

${ }^{9}$ Marsilius z Padovy (1933, s. 63).

${ }^{10}$ Tamtéž, s. 69, 63 \& 64; Co se chlapců týče, ti jsou ovšem potenciální občané.

${ }^{11}$ Tamtéž, s. 452. 
tehdejší kancléř Thomas Cromwell. Z textu však byly vypuštěny pasáže, které se týkaly omezování vladařské moci. Příznivě byl spis přijímán v prostředí německé reformace; do němčiny byl přeložen v roce 1545. V Německu (např. ve Frankfurtu a Heidelberku) pak byla mnohokrát publikována latinská verze spisu v letech 1592-1692 (přičemž na počátku Třicetileté války, totiž v letech 1621-1623, vyšel třikrát).

Obrat'me však nyní pozornost k rozboru hlavních ideových momentů Dantova spisu De monarchia. Tématem knihy je tzv. „časná monarchie“ („monarchia temporalis“), kterou Dante odlišuje od „monarchia aeterna“, jež je věčnou Boží vládou nad stvořeným univerzem, kterého je lidská časná jedinovláda součástí. Na počátku druhé knihy vymezuje Dante smysl koncipování svého politologického traktátu tím, že chce pojednat o ideji a pojmu „časné monarchie“ a že se chce v souvislosti s tím soustřredit především na řešení tří sporných otázek, jež jím předložený koncept nastoluje. „Časnou monarchii“ definuje Dante následujícími slovy:

,jest tedy časná monarchie, kterou nazývají také císařstvím, vláda jediného vládce nade všemi lidmi v čase, anebo v tom i nad tím vším, co se časem měří". 12

Ve třech oddílech, jež spis $O$ jediné vládě tvoří, pojednává Alighieri o oněch třech otázkách, respektive problémech, jež formuluje následujícím způsobem:

především je sporné a vyžaduje řešení, zda je monarchie nezbytně zapotřebí k tomu, aby světu bylo dobře; zadruhé, zda si právem přisvojil národ římský úřad monarchy; a zatřetí, zda je monarchovo oprávnění k moci závislé bezprostředně na Bohu či na nějakém služebníku či zástupci božím. “13

Zodpovězení této otázky souviselo s aktuálním a velmi dramaticky probíhajícím politickým a ideovým zápasem o prioritu duchovní (papežské) či světské (především císařské) moci. Obdobně charakterizuje Dante cíl svého předsevzetí na konci poslední kapitoly třetího oddílu, kde zároveň konstatuje, že zodpovězením oněch tř́i základních otázek vyloupl ze slupky jádro politicko-filosofického problému jediné vlády. ${ }^{14}$

V této studii se nebudu zabývat tím, jak Dante všechny vytyčené problémy řešil, nýbrž zaměřím se jen na povahu jeho filosofické argumentace pro legitimitu vlády světového monarchy, jenž jediný je schopen zajistit trvalý mír, který je předpokladem

12 Dante (1989, s. 62): „Est ergo temporalis Monarchia, quam dicunt ,Imperium“ unicus principatus et super omnes in tempore vel in hiis et super hiis que tempore mensurantur."; česky: O jediné vládě (1942, s. 42-43).

${ }^{13}$ Tamtéž: ,... primo nanque dubitatur et queritur an ad bene esse mundi necessaria sit; secundo an Romanu populus de iure Monarche offitium sibi asciverit; et tertio an auctoritas Monarche dependeat a Deo immediate vel ab alio, Dei ministro seu vicario.“; česky s. 43.

${ }^{14}$ Tamtéž, s. 246; česky s. 165. 
plné realizace duchovní (intelektuální) potence lidského rodu jako takového. ${ }^{15}$ Jak vysoce si Dante mezi ostatními hodnotami, jež jsou pro člověka atraktivní, cenil míru, dokazuje ono místo v textu De monarchia, v němž se odvolává na skutečnost, že nejvyšší hodnota míru mezi všemi dobry je legitimizována i samotným Bohem. Upomíná na to místo Bible, kde jsou shůry osloveni pastýři, shromáždění kolem narozeného Ježíše, odkud prý nezaznělo „... ani slovo bohatství, ani rozkoše, ani pocty, ani dlouhý život, ani zdraví, ani síla, ani krása, nýbrž mír ...“. ${ }^{16}$ Dantovým mottem se tak stává věta z Lukášova evangelia, která i k nám každoročně zaznívá ve vánoční čas: „Sláva na výsostech Bohu a na zemi pokoj lidem dobré vi̊le. "17 Dante poukazuje též na to, že Ježíšovo pozdravení ,pokoj vám“ stalo se, jak osvědčují listy apoštola Pavla, pozdravením všech křest'anů. ${ }^{18}$

Apologie potřebnosti a prospěšnosti světového císařství a postavení jeho vládce se na prvém místě opírá o řadu filosofických argumentů, k nimž nyní obrátím pozornost. Jestliže Alighieri $\mathrm{v}$ tomto svém počínání vehementně využívá formulace $\mathrm{z}$ různých Aristotelových spisů, pak je ovšem nutné konstatovat, že je využívá (ba patrně i zneužívá) proti smyslu tradice původní aristotelské politické filosofie, jejímž ideálem jistě nebyla podoba některé ze světových monarchií. ${ }^{19}$

Všimněme si nyní způsobu, jakým Dante Aristotelovy názory ve svých výkladech aplikuje, a začněme nejvznešenější částí filosofie, jíž byla metafyzika. Ideové základy Alighieriho přístupu se odhalují například na začátku patnácté kapitoly první knihy, kde Dante využívá k prosazování ideje celosvětové monarchie jako nejlepšího politického uspořádání života lidstva onu část aristotelské filosofie, jíž byla nauka o transcendentáliích, jež byla ve scholastice dále rozpracována a hojně diskutována a např́klad u Tomáše se stala jednou z hlavních složek jeho metafyziky. ${ }^{20}$ Ve zmíněné kapitole De monarchia obrací se Dante k oněm pasážím Aristotelových spisů, v nichž se pojednává o jsoucnu a dvou jeho dalších určeních, totiž ,jednu“‘21 a „,dobru“ ${ }^{\text {‘22 }}$. Pro Dantovu argumentaci v De monarchia je charakteristické jeho tvrzení, že:

${ }^{15}$ Dante ovšem neměl na mysli jen plnou realizaci všech možností lidského intelektu, ale i všech činností řízených rozumem a vlastně i komplexní kultivaci lidského rodu.

${ }^{16}$ Tamtéž, s. 70 \& 72; česky s. 48.

${ }^{17}$ Bible, Nový zákon, Lukáš, 2,13.

${ }^{18}$ Dante (1989, s. 72); česky: O jediné vládè (1942, s. 48-49); Bible, Nový zákon, Jan 20,21;26; Matouš 10,12; Pavlovy listy: 1.Korinstkým 1,3; 2. Korintským 1,2; Efezským 1,2; Galatským 1,3 .

${ }_{19}$ Nelze ovšem nepoznamenat, že právě Aristotelés byl vychovatelem Alexandra Makedonského, jenž vytvořil, byt' nakrátko, jednu z největších říší v historii lidstva.

${ }^{20}$ Floss (2004, s. 218); Tím, že Dante nehovoř́ o jednu a dobru jako o atributech jsoucna, realizuje ovšem spíše Tomášovo pojetí, v němž nejde o atributivní vztah mezi jednotlivými transcendentáliemi; viz. Akvinský (1856-1858, I, d. 8, q. 1, a. 3); srv. též: Akvinský (19701976, q. 1, a. 1; 21,3); Akvinský (1937-1940, I, q. 5, a. 2; q. 16, a. 4, ad 2).

${ }^{21}$ Aristotelés (1996a, X, 1-2).

${ }^{22}$ Aristotelés (1996b, I, 4 (1096a 20 n.)). 
„Jsoucno totiž od přirozenosti jde dřív než jedno, a jedno zase dřive než dobro. “23

Dante z toho odvozuje, že být jedno je kořenem toho, co je býti dobrem a opak jednoho, tj. mnohost, je kořenem toho, co je býti zlem. Dante v tomto kontextu sestupuje až k základům evropského myšlení, jež byly zformovány výrazně i tzv. pythagorejskou deskou kategorií a odvolávaje se na první knihu Aristotelovy Metafyziky poukazuje na to, že Pythagoras kladl jedno po boku dobra a mnohost po boku zla. ${ }^{24}$ Alighieri odívá starou pythagorejskou nauku do křest'anského hávu, nebot' pohrdání jednem a obracení se k mnohosti označuje za hřích, čímž dává najevo, že hříchem je koneckonců i odpírání jím propagované světové monarchie, která má být nastolena, nebot' ta vede k uskutečnění nejvyšší možné jednoty a s ní i lidské svornosti, kterou podle autora doporučuje i Bible. V kontextu vývoje evropského myšlení je na tomto místě třeba zdůraznit, že odmítnutím těchto a jim v dějinách podobných apoteóz priority a nároků jednoty oproti všem formám mnohosti se profilovala programově postmoderna (napřr. J. F. Lyotard, W. Welsch, P. Sloterdijk aj.), která naopak hlásala prioritu mnohosti nad jednotou a viděla ve svém novém, o tento ideový fundament se opírajícím přehodnocení vztahu dalších klíčových určení (souhlas - nesouhlas, obecné - jedinečné aj.), ideový základ demokracie. ${ }^{25}$

Pokročíme-li dále ve zkoumání základů Dantovy politické filosofie, pak je relevantní Dantovo tvrzení, že z šesté a sedmé kapitoly první knihy vyplývá, že to, co je vzhledem k něčemu celkem, je vůči jinému částí. Světová monarchie je zahrnující celek všech stupňovitě řazených částí, v nichž ty vyšší jsou vždy jakýmsi celkem nižších (království se skládá z knížectví, pak z měst či obcí, jež sestávají ze sousedstev, a posléze rodin). Světová monarchie jako jejich celek je však částí vesmírné monarchie Boží. A protože se nejnižší společenský celek, tj. rodina, skládá z lidských individuí, pak výše zmíněná stupnice představuje postupný růst jednoty z původní mnohosti. Avšak jedině v tom, co je v určitém smyslu nejvyšší, je založena jednota a řád všeho nižšího. Shrnuto Dantovými slovy:

„A tak všechny připomenuté části nižší nežli království, i království sama, musí se pořádati směrem $\mathrm{k}$ jednomu vládci nebo vládě, to jest $\mathrm{k}$ monarchovi nebo monarchii. “26

Dante se pohybuje v okruhu Aristotelových úvah o částečném a celkovém řádu, jenž je vysvětlován na vztahu jednotlivých částí shromážděného vojska k sobě

${ }^{23}$ Dante (1989, s. 106): „Ens enim natura precedit unum, unum vero bonum ... “; česky: $O$ jediné vládě (1942, s. 70).

${ }^{24}$ Tamtéž, s. 108; česky s. 71.

${ }^{25}$ Welsch (1988).

${ }^{26}$ Dante (1989, s. 78): „Et sic omnes partes prenotare infra regna et ipsa regna ordinari debent ad unum principem sive principatum, hoc est ad Monarcham sive Monarchiam.“; česky: $O$ jediné vládě (1942, s. 52). 
navzájem a jejich řad vzhledem $\mathrm{k}$ vojevůdci. Tento aristotelský obraz ${ }^{27}$, využívaný k upřednostňování monarchie před jinými státními zřízeními, nacházíme nejen $\mathrm{v} D e$ monarchia $^{28}$, ale též kupříkladu u Mikuláše Kusánského ${ }^{29}$.

V rámci shromažd'ování důkazů o výhodnosti světové říše, řízené jediným panovníkem, formuluje Dante zásadu, jež anticipuje princip „ekonomie“ myšlení, ztělesněný Ockhamovou břitvou. ${ }^{30}$ Ve čtrnácté kapitole první knihy totiž Dante píše, že „... co může býti vykonáno jedním, jest lépe, aby bylo vykonáno jedním, nežli větším počtem“. 31

Významnou součástí metafyziky byla i nauka o př́icinách, z níž Dante také čerpá argumenty pro prosazování svého politického ideálu. Je tomu tak např́klad na onom místě spisu $O$ jediné vládě, kde hodnotí hierarchii příčin, podle jejich extenzity. S odvoláním se na Knihu o př́činách (Liber de causis), ${ }^{32}$ Dante tvrdí, že čím je nějaká přičina obecnější, tím významnější postavení má mezi ostatními příčinami a ty pak fungují jako jakési příčiny nižší jen skrze příčiny vyšší, respektive nejvyšší. ${ }^{33}$ Zároveň pak čím je příčina obecnější, a tudíž čím je i více příčinou, tím intenzivněji se vztahuje ke svému účinku, což Dante charakterizuje jako lásku př́íciny ke svému účinku. Z těchto ontologicky laděných tezí vyvozuje pak Alighieri pro svou politickou filosofii následující závěr:

„Poněvadž tedy monarcha je mezi smrtelníky nejvšeobecnější příčinou toho, aby lidé dobře žili ... vyplývá z toho, že on nejvíce miluje lidské dobro. “34

Obdobně je monarcha i nejpưsobivější příčinou nastolení spravedlnosti, která je předpokladem udržování všeobecného míru.

Než obrátím pozornost $\mathrm{k}$ antropologicko-psychologickým argumentům pro jedinovládu, je třeba na závěr úvah o Dantových metafyzických argumentech konstatovat, že jejich jádrem je přesvědčení, že tam, kde je něčeho více a méně musí být

\footnotetext{
${ }^{27}$ Aristotelés (1996, XII, 10 (1075a 13 nn.)).

${ }^{28}$ Dante (1989, s. 78); česky: O jediné vládě (1942, s. 52).

${ }^{29}$ Kusánský (1963; 1964; 1965; 1968, III (283:1-11), s. 321).

${ }^{30}$ Floss (2004, s. 331-332): „Nejznámější Ockhamovy formulace tohoto omezujícího principu zní: entia non sunt multiplicanda praeter necessitatem (,není třeba zmnožovat entity, pokud to není nutné") a frustra fit per plura, quod potest fieri per pauciora (,zbytečné je činit s větším počtem [rozuměj: principů], co lze učiniti s menším“"). Břitvou nenazval tento princip samotný Ockham; termín novacula Ockhami et nominalium pochází ze sedmnáctého století od lovaňského teologa a filosofa Liberta Frommonda.“

${ }^{31}$ Dante (1989, s. 102): „Et quod potest fieri per unum, melius est per unum fieri quam per plura."; česky: O jediné vládě (1942, s. 67).

${ }^{32}$ K Liber de causis (český překlad Aristotelés, 1999) viz Floss (2004 s. 191).

${ }^{33}$ Aristotelés (1999, s. 48-49); Dante (1989, s. 92): „Každá prvotní př́íčina má na svůj účinek větší vliv než všeobecná příčina druhotná.“; česky: O jediné vládě (1942, s. 61).

${ }^{34}$ Dante (1989, s. 92): „Quod igitur Monarcha sit universalissima causa inter mortales ut homines bene vivant ... consequens est quod bonum hominum ab eo maxime diligatur.“; česky: O jediné vládě (1942, s. 6).
} 
téhož nejvíce, v našem př́ípadě politické jednoty, resp. jedinosti vlády. Je jistě pozoruhodné, že na obdobném metafyzickém principu bylo koncipováno jedno ze zdůvodnění existence Boží, jak ukazuje například Anselm ve svém Monologiu ${ }^{35}$ nebo Tomáš v tzv. „čtvrté cestě“. ${ }^{36}$ Nezbytnost existence jediného světového vladaře je tedy dovozována podobným postupem jako nepochybnost existence Boží (tato analogie byla pak jedním ze zdrojů zbožštění monarchistické moci).

Přistoupíme-li nyní k analýze výše zmíněných antropologicko-psychologických důvodů pro přednost světové monarchie a světového monarchy, pak jedním z hlavních témat je problematika spravedlnosti. Při řešení této problematiky se Dante dovolává zvláště Aristotelovy Etiky Níkomachovy. Spravedlnost jakožto ctnost, jež se má uplatňovat ve veřejné sféře lidského života je autorem spisu De monarchia zkoumána vzhledem ke dvěma mocným mohutnostem lidské duše, totiž žádostivosti a lásce. Spolu s Aristotelem považuje Dante žádostivost za největší nebezpečí pro výkon spravedlnosti, zatímco láska je pro něho faktorem, který spravedlnost podněcuje a posiluje. K největší spravedlnosti je proto disponován ten, kdo z povahy svého společenského postavení nemá žádný důvod k žádostivosti, je však disponován k maximu lásky.

Podle autora je vládce celosvětové říše z povahy svého úřadu žádostivosti zbaven, nebot' monarcha opravdu „... nemá, čeho by si mohl přáti, nebot' jeho pravomoc omezuje jedině oceán...“. ${ }^{37}$ Vladařská žádostivost je zde tedy ztotožněna s touhou po územní expanzi, jež je motivem jednání všech - jen omezená území spravujících panovníků. Oceán, jenž omýval tehdy známý svět, byl tudíž tím, co činilo územní žádostivost monarchy bezpředmětnou, čehož, jak Dante zdůrazňuje, se nedostává jiným vládcům „,... jejichž panství hraničí s jinými, např́klad panství krále Kastilského hraničí s panstvím krále Aragonského“. ${ }^{38}$ Dante bere „geopolitické“ omezení panovnické žádostivosti natolik vážně, že z parafrázovaných úvah činí závěr:

„Z toho plyne, že monarcha může býti mezi lidmi nejčistším nositelem spravedlnosti. “39

Obrat'me se nyní k lásce, která podle Alighieriho spravedlnost na rozdíl od žádostivosti zbystřuje a osvěcuje. Žádostivost a láska (,cupiditas et charitas“) liší se tím, že žádostivost, jež vzniká pohrdáním soběstačností (,perseitas“) zaměřuje člověka „na jiné věci“, „...láska však, pohrdnuvši všemi jinými věcmi, vyhledává Boha a

\footnotetext{
${ }^{35}$ Anselm z Cantenbury (1984, s. 148-150); viz též: Floss (2004, s. 114).

${ }^{36}$ Akvinský (1937-1940, I, q. 2, art. 3 resp.); viz též: Floss (2004, s. 235).

${ }^{37}$ Dante (1989, s. 90); česky: O jediné vládé (1942, s. 60).

${ }^{38}$ Tamtéž.

${ }^{39}$ Tamtéž: „Ex quo sequitur quod Monarcha sincerissimum inter morales iustitie possit esse subiectum.“
} 
člověka, a tím dobro člověkovo“. ${ }^{40}$ Skutečnost, že jak Dante výslovně říká ,... monarchovi musí býti vlastní správné milování lidí“ je prý zřejmá z toho, že „,všechno milovatelné je tím více milováno, čím je bližší milujícímu“". ${ }^{41}$ Tento obecně platný princip, promítnutý do Dantovy představy o architektuře moci, podle níž všichni konšelé, knížata a králové opírají legitimitu svých úřadů o moc císařovu, umožňuje autorovi konstatovat, že lidé jsou monarchovi jakožto základu vší moci vlastně blíže než jiným vládcům a „tudíž od něho nejvíc jsou nebo mají býti milováni““. ${ }^{2}$

Láska je v následném textu v politické sféře konkretizována jako distribuce péče, přičemž se v duchu předchozích úvah vyslovuje názor, že monarcha má péči o všechny původněji a bezprostředněji, kdežto jiní vládcové tak činí jen prostřednictvím monarchovým, ,protože jejich péče je odvozena z oné péče nejvyšší“ “43 Císař, který na základě těchto úvah má nejmenší sklon k žádostivosti a zároveň má největší předpoklady pro pravou lásku a účinnou péči, je též nejlepším garantem spravedlnosti, nebot' má díky svému postavení i největší moc k jejímu prosazování.

Proto dospívá Dante $\mathrm{k}$ přesvědčení, že autoritu císaře světové řîše a také jeho nezávislost na papeži (což vehementně popírali ,papalisté") nejlépe zdůvodní tím, že prokáže její odvoditelnost od instance nejvyšší, jíž je Bůh, který zřídil řád nebes (resp. jejich pravidelný otáčivý pohyb), na němž je závislý řád světa. ${ }^{44}$ Bủh jako garant takto komponovaného řádu univerza je též tím, kdo jedině císaře „vybírá“ a definitivně stvrzuje, protože nad sebou nemá nikoho vyššího. ${ }^{45}$

Je ovšem třeba upozornit, že ačkoliv se Dantova argumentace nutnosti zřízení světové monarchie opírá o abstraktní filosofické argumenty, je propojena též s mnohými aspekty historie i dobového stavu politických zř́zení. Koncept jediné vlády opírající se o metafyzické argumenty vsazuje Dante do reálné politické situace svého století i tím, že vlastně nechce zřídit nějaký nový úřad, nýbrž chce jen univerzalizovat postavení, moc a práva úřadu již stávajícího, totiž císaře svaté říše římské. V tomto momentě stává se však jeho doktrína o přímém původu monarchovy moci od samotného Boha zpochybnitelnou institutem volby císaře říše římské, jenž nebyl

${ }^{40}$ Tamtéž: ,... cupiditas nanque, perseitate hominum spreta, querit alia; charitas vero, spretis aliis omnibus, querit Deum et dominem, et per consequens bonum hominis.“

${ }^{41}$ Tamtéž, s. 92; česky s. 61. Všimněme si, že Dante, jenž ve své Božské komedii disponuje působivým vhledem do propasti lidské duše, pracuje v De Monarchia s metafyzickým schématem dokonalosti světového vladaře, jakoby ani nešlo o člověka. Vladař jako jakýsi nadčlověk, zbavený jen z titulu svého mimořádného postavení všech lidských slabostí, může se posléze snadno stát objektem divinizace moci.

${ }^{42}$ Tamtéž.

${ }^{43}$ Tamtéž.

${ }^{44}$ Diskutuje-li se o tom, do jaké míry byl Dante ovlivněn dobovým averroismem, pak je v právě sledovaném kontextu třeba vzít v úvahu, že přímá intervence Boží ve výběru panovníka a odvozování jeho moci přímo od Boha byla jistě v rozporu s názorem rigorózních averroistů, kteří odmítali působení Boží prozřetelnosti v podměsíčné sférée univerza.

${ }^{45}$ Dante (1989, s. 246); česky: O jediné vládě (1942, s. 164). 
panovníkem dědičným, nýbrž voleným. Proto Dante prohlašuje, že světového vladaře nemá volit nikdo z lidí, nebot' jeho volba je vyhrazena pouze Bohu, pročež se domnívá, že ti, kteří císaře dosud volili, tedy kurfiřti, by měli být pouze ,... pokládáni za ohlašovatele prožretelnosti boží“ ${ }^{46}$ Je patrné, že volitelnost panovníka oslabovala v Dantových očích božskou legitimitu jeho moci. Ačkoliv označil kurfiřty za ohlašovatele vůle Boží, připouští, že se ovšem může stát, že někteří z nich (nebo dokonce všichni!) jsou zaslepeni žádostivostí, nebot' „... nerozeznávají tvár̆nost rozhodnutí božího“. ${ }^{47}$

Při posuzování Dantova politického projektu je ovšem třeba vzít na vědomí, že světová řîše, nastolující svornost, pořádek a mírovou kooperaci, neměla být unitárním represivním superstátem, nebot' přirozené rozdíly mezi různými knížectvími a královstvími, jakož i významnými městy té doby, by neměly být eliminovány přísně centralizovanou světovou vládou. Dante je naopak hlasatelem určité míry subsidiarity a přiznává dokonce, že v jednotlivých částech světové řríše budou muset pro určitou oblast života platit specifické zákony související s mentalitou tamních národů a podnebím, $\mathrm{v}$ němž žijí a že světový vladař nebude např́íklad zasahovat do soudních procesů probíhajících v některém $\mathrm{z}$ četných měst říše. ${ }^{48}$

Přistoupíme-li nyní k obecnějšímu hodnocení Dantova spisu, pak lze konstatovat, že Dante se, byt' osobitým způsobem, podílel na oné výrazné duchovní inklinaci čtrnáctého století, jež spočívala nikoliv $\mathrm{v}$ harmonizaci, ale $\mathrm{v}$ separaci: filosofie a teologie, rozumu a víry, politiky a náboženství, státu a církve (papežství). Jeho angažmá $\mathrm{v}$ tomto procesu nepochybně přispělo $\mathrm{k}$ ještě většímu zhodnocení dignity přirozeného a otevíralo i dveře laicizaci politického a kulturního života společnosti. Na druhé straně je však třeba si zároveň uvědomit, že Dantova politická koncepce obsahovala i prvky, které nebyly příznivé filosofickému zhodnocení individuálního, s nímž se v různých podobách setkáváme např. u Tomáše Akvinského, Jana Dunse Scota nebo Viléma Ockhama. ${ }^{49}$ Patrně především pod vlivem averroismu rozvíjí Dante svou politickou filosofii jakožto koncepci rozvoje lidského rodu (kdy jednotlivá individua jsou jen prostředkem realizace rozvoje lidského druhu).

\footnotetext{
${ }^{46}$ Tamtéž.

${ }^{47}$ Tamtéž, s. 246; česky s. 164-165. Zatímco volitelnosti světového monarchy, resp. císaře, se dotýká alespoň tímto způsobem, volitelností na nižších stupních politického uspořádání společnosti, např. konšelů nebo ve specifickém případě králů, se nezabývá vůbec. Jestliže si uvědomíme, že všechny formy volitelnosti nějakého úřadu byly intenzivní formou oslabování neotřesitelnosti jakékoliv moci, pak to znamená, že byly „eo ipso“ významným momentem v genezi demokratizačních sociálních hnutí a posléze i samotné demokracie jakožto politického zřízení. Absencí problematiky volitelnosti liší se Dantova De monarchia od o několik let mladšího Marsiliova spisu Defensor pacis.

${ }^{48}$ Tamtéž, s. 104-106; česky s. 68-70.

${ }^{49}$ K Tomášově zhodnocení individuality viz: Floss (2004, s. 243, 260); individualita u Scota: Floss (2014, s. 267); u Ockhama: tamtéž, s. 277; viz též: Floss (1998, s. 268-269).
} 
$\mathrm{Na}$ tomto místě budu konfrontovat Dantovy názory $\mathrm{s}$ koncepcí Tomáše Akvinského. V Tomášových politických koncepcích promítá se jeho antropologická nauka o individuu a osobě (,,persona“ $).{ }^{50}$ Jako individuum plní každý člověk určitou sociální funkci a zaujímá více či méně subordinované postavení, jako „osoba“ (,persona“) však není nikomu poddán a není zde pro stát, nýbrž stát je pro něho. Svoboda jeho rozhodování a integrita jeho svědomí, jež spolu s intelektem tvoří základní složky osoby, nesmí být potlačována žádnou mocí a ve jménu jakýchkoliv, byt' i obecně prospěšných zájmů. Hlásat tento postoj uprostř̌ed hierarchicky uspořádané společnosti bylo jistě něčím mimořádným a bylo a ve svých konsekvencích stále je nepřijatelné nejen všem obhájcům totalitního pojetí státu, ale je nesympatické i těm liberálům, jejichž antropologie staví na některé z podob moderního redukcionismu. ${ }^{51}$

${ }^{50}$ Floss (2004, s. 211 nn.); tamtéž, s. 260. Člověk jako persona v kontextu Tomášovy etiky je integrální entitou, která je daná svobodou vůle a svědomí; Akvinský (1937-1940, I, q. 60, a. 5; II-II, q. 64, a 2; q. 65, a. 1; q. 26, a. 4). „Podl’a učenia svätého Tomáša však celý človek ako indivíduum je naozaj ako čast' v štáte a je zameraný pre dobro štátu, ako čast' je zameraná pre dobro celku, pre spoločné dobro, ktoré je božskejšie ... No ked' ide o osobu ako takú, vzt'ah je obrátený a l'udská spoločnost' je zameraná pre večné záujmy osoby a pre jej vlastné dobro, ktorym koniec koncov je ,oddelené spoločné Dobro“ celého vesmíru, chcem povedat' sám Boh; lebo každá ĺudská osoba, vzatá čisto ako taká, znamená celok a každá ĺudská osoba je zameraná priamo k Bohu, jako k svojmu poslednému ciel'u, a preto podl'a poriadku lásky ničomu inému nemá dávat' prednost pred sebou, iba Bohu. Teda $\mathrm{v}$ každom z nás indivíduum je pre štát a musí sa v prípade potreby obětovat zaň, ako sa stáva v spravodlivej vojně. Ale osoba je pre Boha; a štát je pre osobu, myslím pre umožnenie dosiahnutia mravného a duchovného života a božieho dobra, ktoré je samotným určením a konečnou príčinou osobnosti.“"Maritain (1947, s. 23-24).

${ }^{51}$ Problematikou moderního redukcionismu jsem se zabýval v řadě svých studií, především však v článku Úvaha o Kalivodově obrazu člověka (Floss, 2000), z níž nyní uvedu jeden zásadní úsek: „Redukcionisté, kteří jsou vždy i deterministé onoho typu, který určuje povaha jejich redukcionismu, odhalují všechny duševní aktivity člověka, včetně poznání, jako entity abalietní, nevlastní a určené, ač jejich odhalení a tvrzení jsou právě aktem takto dehonestovaného poznání. Vědeckou či filosofickou suverenitou jejich teorií však ona nesamostatnost duchovní sféry (včetně poznání) neotřásá. Redukcionisté jsou tak vědci a myslitelé s Janusovou dvojí tváríi.

Pokud jsou redukcionisté důslední, mají pouze dvě možnosti: bud’ rozšíritit své analýzy determinovanosti o analýzu determinovanosti tvrzení této determinovanosti, nebo ze své „transcendentální pozice“ vyvodit patřičné závěry. V prvním př́ípadě by to znamenalo relevanci předkládaného konceptu krajním způsobem zrelativizovat a zesubjektivizovat, a tím ho zbavit všech nároků na vědeckost, ve druhém př́ípadě by to znamenalo pozice redukcionismu opustit.

Redukcionismus, který je ve větší či menší míře př́itomen $v$ mnoha moderních filosofických a vědeckých proudech (např. ve freudismu, behaviorismu, marxismu a uplatňuje se $\mathrm{v}$ určité míře i v moderní sociologii, ve francouzském strukturalismu aj.) a který je důsledkem antimetafyzického „zvědečtění filosofie“, má pseudometafyzický a totalizující charakter. Určitá sféra jsoucího, ba často spíše určitá fakta této sféry jsou privilegována a postavena nad ostatní fakta; vše zbývající je pak vyloženo z jejich pozice. Tento model aplikovaný ve vědě byl pak sociálně aplikován v totalitních režimech. Antimetafyzická moderna tak zplodila různé pseudometafyziky: zatímco tradiční metafyzika vycházela $\mathrm{z}$ analýzy jsoucího jako takového, vycházejí moderní pseudometafyziky jen z určitého regionu jsoucího a jejich prizmatem pak redukcionistickým způsobem (a jak jinak!) interpretují veškeré ostatní jsoucí.“; Floss (2012, s. 211-212). 
Dantova politická filosofie nepracuje s výše zmíněným rozlišením, což znamená, že se rozvíjí jen v perspektivě individua (jež je prostředkem dovršení potencí lidského druhu), nikoliv v perspektivě osoby, jež byla u Tomáše chápána jako to, co sféru politického přesahuje. Tento fakt poskytuje nám př́ležitost zamyslet se ještě jednou nad odstavcem, v němž jsem formuloval to, co bych nyní nazval předběžným hodnocením základních historicko-filosofických intencí spisu De monarchia. Vzhledem k tomu, že jedinec je zde pojat jen jako individuum fungující v rámci celku, jež ho převyšuje, a že Dante nerozpracovává ideu osoby, která naopak tento celek transcenduje, oploštil sféru přirozeného, jemuž zajistil autonomii vzhledem $\mathrm{k}$ nadpřirozenému.

„Persona“ byla tím, co zabraňovalo politickému řádu, aby si na jedince (moderněji řečeno: občana) mohl činit absolutní nároky. Učení o osobě principiálně znemožňovalo vznik jakékoliv absolutistické teorie státu a moci. Jestliže se snoubilo i s ideou o původu veškeré pozemské moci z lidu, respektive $\mathrm{z}$ jeho vůle či souhlasu, vytvářely se tím ideové předpoklady pro vznik demokratického uspořádání státu. Vzhledem k tomu, co bylo o Dantově politické filosofii řečeno, nepřekvapí, že - opět v protikladu $\mathrm{k}$ Tomášovi - nechápal panovníka jako nejvyššího představitele lidu, nýbrž legitimizoval jeho autoritu jen „shora“ a odvozoval ji od Boha. Vládce světové rrúše je analogií Boha, nebot' tak jako jediný Bůh vládne vesmíru, tak i císař vládne jedné světové říši ${ }^{52}$ Dante však nezbožštuje jen samotný úřad vladaře světové monarchie, nýbrž až nehorázným způsobem oslavuje konkrétního adepta tohoto úřadu, za něhož považoval tehdejšího císaře Svaté rríše římské Jindřicha VII. Dante zachází dokonce tak daleko, že o tomto panovníkovi mluví jako o beránku Božím, který snímá hříchy světa a v hierarchizující vizi Božské komedie jej v tzv. empyreu „usazuje“ na trůn v blízkosti pána dějin Krista. ${ }^{53}$

Na jedné straně lze hovořit o určitých sekularizačních momentech Dantova spisu, na druhé straně je ovšem nutno vidět, že to, co bylo pro novodobou politickou filosofii jedním z hlavních témat, totiž legitimita moci panovníka, bylo obdařeno atributem opačného charakteru. Dante sice přispěl k oddělení politiky a náboženství, jakož i moci světské a duchovní, zároveň však moc císaře absolutizoval, a tudíž zbožštil. Odvozování jeho moci pouze od Boha legitimizuje divinální povahu moci. Absolutizace světské moci byla vevropských dějinách ideou stejně neblahou jako absolutizace pozemské moci papeže, měla však delší život a tíživější a dlouhodobější důsledky (paradoxně se tak stalo navzdory tomu, že Dante se snažil o oddělení politiky a náboženství). Absolutizace světské moci a sféry politiky v nejrůznějších podobách

\footnotetext{
${ }^{52}$ Dante (1989, s. 82): „Ergo humanum genus uni principi subiacens maxime Deo assimilatur, et per consequens maxime est secundum divinam intentionem: quod est bene et optime se habere ...“; ,... pokolení lidské, podléhá-li jedinému vládci, připodobňuje se co nejvíce Bohu, a tím žije nejvíce podle Božího záměru, jímž je, aby se mělo dobře ..."; česky: O jediné vládě (1942, s. 54).

${ }^{53}$ Müller, (2011, s. 23).
} 
získávala natolik religiózní charakter, že například Hans Maier oprávněně pojednává o moderních totalitarismech jako o politických náboženstvích. ${ }^{54}$

Je ovšem třeba zdůraznit, že divinizace panovníkovy moci, založená jejím božským původem, v Dantově době neznamenala zbožštění státu a dalo by se dokonce říci, že takovému názoru stála v cestě. Zatím byla zbožštěna jen samotná moc panovníka, nikoliv ještě stát, v němž byla vykonávána. Když však byla v novověku a zvláště v moderní době, především díky odmítání metafyziky, otř̌esena idea Boží transcendence, byla divinizace panovnické moci přenesena na zbožštění státu, jemuž je každé lidské individuum zcela poddáno a pro jehož zdárné fungování musí být ochotno přinést jakoukoliv obět'.

Závěrem této studie však musím poukázat na skutečnost, která prvořadost a nezávislost postavení světového monarchy poněkud omezuje (o podobných prvcích zmínil jsem se ovšem již i v předchozím textu, nap̌r. o určité formě subsidiarity). V prvním dílu Cest evropského myšlení jsem se stručně dotkl ideje služebnosti v souvislosti s často uváděným, ale neadekvátně vykládaným výrokem, že filosofie je služebnicí teologie (,philosophia ancilla theologiae“).

„Služebnost nebyla vyhrazena jen společensky nižším vrstvám, nýbrž i panovník byl v určitém smyslu služebníkem lidu a papež služebníkem církve. Byla tudíž výrazem vzájemnosti a relativizovala vertikalitu středověkého společenského řádu, stojícího na subordinaci a supremaci. “55

S touto ideou setkáváme se ve specifické podobě i u Danta, a to v kontextu výkladu o lidském svobodném rozhodování hned ve dvanácté kapitole první knihy.

Na tomto místě chtěl bych jen upozornit na výsledek sepětí názoru o svobodném rozhodování se středověkou ideou služebnosti. Když totiž Alighieri obhajuje svou univerzální monarchii jakožto státní zřízení, v němž jsou lidé nejvíce svobodní, protože

\footnotetext{
${ }^{54}$ Maier (1995); Se zneužitím Dantovy koncepce světového monarchy setkáváme se i v doprovodném textu překladu „De monarchia“, který používám k českým citacím. Editor Josef Kliment, jenž byl svého času sekretářem protektorátního prezidenta E. Háchy, opírající se o knihu O. Ditricha Revoluce myšlení (Praha 1941) viděl v totalitním vůdcovském principu a v nacistické kulturní rekonstrukci „,velké Evropy“ moderní naplnění Dantových ideálů: „Dante poznal všechny nevýhody mnohohlavých vládních sborů, a proto neváhal tak důrazně se postaviti za princip schopného vedoucího jednotlivce. Jeho víra ve schopnost jedince a v neschopnost množství jest i naší vírou, zejména když i my jsme mohli na mnohých demokratických institucích dřívější doby poznati všechny nevýhody mnohohlavých vedoucích orgánů. A pokud jde o Dantův boj proti rozkladnému principu dílčích suverenit a zaujetí pro myšlenku vrchního řízení kulturní Evropy, zní jeho důvody přizpůsobené dnešní terminologii velmi přsesvědčivě a časově.“ Kliment (1942, s. 28); Možnost zneužití Dantovy koncepce spočívala i v tom, že jeho světová monarchie vlastně byla rozšířením římské říše německého národa, což se mohlo hodit nárokům na opětovné vedení Evropy německým národem ve 20. stol., ostatně proto se mluvilo o třetí říši!

${ }^{55}$ Floss (2004, s. 83-84).
} 
jsou nejvíce „pro sebe“, pak k tomu dodává, že „nejsou totiž měšt’ané pro konšely ani lid pro krále, nýbrž obráceně, konšelé jsou pro měšt’any a král pro lid... “56 To, co platí o konšelech a králích, týká se o to větší měrou světového monarchy. Nejde ovšem jen o služebnost vyšších k nižším, ale i nižších k vyšším, tedy o služebnost vzájemnou. Tato vzájemnost není však reciproční symetricky, což vyplývá z následujícího výroku:

„... konšel nebo král, jakkoli jsou se zřením k cestě pány jiných, naproti tomu se zřením k cíli jsou služebníky jiných ... “57

Výkon moci konšelů a králů je tak jen prostředkem, který je službou měšt’anům a lidu jakožto podílníkům na realizaci všech potencí lidského rodu, jenž je podle Danta nejvyšším cílem lidské společnosti v časné dimenzi její existence. Takto chápaná služebnost přispívala $\mathrm{k}$ relativizaci v sociální praxi tvrdě prosazovaného hierarchicky uspořádaného společenského řádu (viz především doktrína o tzv. „trojím lidu“) a patřila do souboru idejí, které vykazovaly každému pozemskému zrrízení a vládnutí jeho meze. Vzrůstající odpor utlačovaných vůči mocným, jenž ve čtrnáctém a patnáctém století vedl k sociálním střetům a nakonec u nás i k revolučním aktivitám, se napájel i z těchto zdrojů.

Závěrem této studie je třeba zdůraznit, že Dantův spis De monarchia je též významným článkem evropské duchovní tradice usilování o nastolení trvalého míru. Akcentace a uchopení tohoto tématu je jednou $\mathrm{z}$ charakteristik nástupu nového typu filosofie politiky a státu, jak kromě Marsiliova díla Defensor pacis dokládá např́klad i pátá část spisu De fato, fortuna et casu, jehož autorem je politik a učenec Collucio Salutati (1331-1406). V textu, napsaném elegantní latinou, vyzývá tento muž, který strávil mnoho let $\mathrm{v}$ úřadu florentského kancléře, horlivě své čtenáře, aby vykročili na cestu k zajištění politického a společenského míru duchovním přimknutím se k základům křest’anské morálky. Salutati apeluje na své současníky, aby se ponořili do srdce, jež touží po lásce, a aby si před oči své mysli postavili Boha a aby pro něj samého milovali nejen svého bližního, ale i své nepřátele. ${ }^{58}$

V čase doznívající renesance kulminuje úsilí o mír v díle českého myslitele Jana Amose Komenského, které bylo jedním z duchovních pilî̌ro moderního úsilí o zajištění světového míru. U Komenského se jednalo až o jakousi „irénickou“ ontologii, vyjádřenou manifestačně v jeho známém Světu v obrazech výrokem: „Omnia sponte fluant, absit violentia rebus“ - „Všechno at' volně plyne a od věcí at' odstoupí násilil“. Moderním světem postupně odhalovaný a osvojovaný Komenského irénický a emendační koncept klestil dějinnou cestu ke zrodu takových institucí, jakými jsou OSN

\footnotetext{
${ }^{56}$ Dante (1989, s. 96, 98): „Non enim cives propter consules nec gens propter regem, sed e converso consules propter cives et rex propter gentem ..."; česky: O jediné vládě (1942, s. 64).

${ }^{57}$ Tamtéž, s. 98: „... quamvis consul sive rex respectu vie sint domini aliorum, respectu autem termini aliorum ministri sunt ..."; česky s. 65.

${ }^{58}$ Salutati, (1985, s. 217-218).
} 
a UNESCO, jež odkazují k Janu Amosovi jako jednomu ze svých duchovních praotců. Ch. L. Montesquieu (1689-1755), který považoval za konstitutivní politickou ctnost lásku k rovnosti a požadavkem oddělení tří základních mocí ve státě preformoval spolu s J. Lockem moderní politické myšlení, považoval mír za první přirozený zákon, jenž je dán Bohem.

\section{Literatura}

Akvinský, T. (1856-1858): Commentum in quatuor libros Sententiarum magistri Petri Lombardi. Typis Petri Fiaccadori, Parma.

Akvinský, T. (1937-1940): Theologická summa. Red. E. Soukup. Edice Krystal, Olomouc. Reprint v roce 2003, Krystal OP, Olomouc.

Akvinský, T. (1970-1976): „Quaestiones disputatae de veritate.“ In T. Akvinský, Opera omnia iussu Leonis XIII P. M. edita, sv. 22, A. Dondaine, Rome.

Anselm z Cantenbury (1984): „Monologion.“ In Anselmi Cantuariensis opera omnia, sv I, ed. F. S. Schmitt, Edinburg 1984, s. 148-150.

Aristotelés (1996a): Metafyzika. Rezek, Praha.

Aristotelés (1996b): Etika Níkomachova. Rezek, Praha.

Aristotelés (1999): Liber de Causis I. Přeložil M. Pokorný. Rezek, Praha.

Bilble, Nový Zákon. Český ekumenický překlad. Česká biblická společnost, 2015.

Cassell, A. K. (2004): The Monarchia Controversy: An Historical Study with Accompanying Translations of Dante Alighieri's Monarchia, Guido Vernani's Refutation of the „Monarchia“ Composed by Dante, and Pope John XXII's Bull Si fratrum, The Catholic University of America Press, Washington.

Dante Alighieri (1960): „Questio de aqua et terra.“ In Le Opere di Dante, vol. 1., E. Pistelli, Firenze.

Dante Alighieri (1966-1967): La Divina commedia (La Commedia secondo l'antica vulgata). G. Petrocchi, Milano; český překlad O. Babler, Božská komedie, Vyšehrad, Praha, 1952.

Dante Alighieri (1989): Monarchia: Lateinisch-Deutsch Studienausgabe. R. Imbach, Ch. Flüeler, Stuttgart; český překlad B. Ryba, O jediné vládě, Melantrich, Praha, 1942.

Dante Alighieri (2007): Peklo. Český překlad V. Mikeš, Academia, Praha.

Di Scipio, G. (1983): „Dante and Politics.“ In The Divine Comedy and the Encyclopedia of Arts and Sciences: Acta of the International Dante Symposium, 13-16 Nov. 1983, eds. G. Di Scipio \& A. Scaglione, John Benjamins Publishing Company, Amsterdam - Philadelphia, 1988, s. 267-284. 
Farnell, S. (1985): The political ideas of The divine comedy: an introduction, Lanham, New York - London.

Ferrante, J. M. (1994): The Political Vision of the „Divine Comedy“. Princeton University Press, Princeton.

Floss, P. (1998): Od počátků novověku ke konci milénia. Vetus Via, Brno.

Floss, P. (2000): "Úvaha o Kalivodově obrazu člověka." In Historicko-filozofické dílo Roberta Kalivody. Mezinárodní kolokvium pořádané u př́ležitosti 10. výročí úmrtí Roberta Kalivody 1.-2. prosince 1999 v Olomouci, Aluze 2000, Př́loha 1., s. $136-160$.

Floss, P. (2004): Cesty evropského myšlení. I. Architekti křest'anského středovékého vědění. Vyšehrad, Praha.

Floss, P. (2012): Meditace na rozhraní epoch. CDK, Brno.

Floss, P. (2014): Cesty evropského myšlení. I. Architekti křest'anského středověkého vědění. 2. vyd, Univerzita Palackého v Olomouci, Olomouc.

Gorni, G. (2008): Dante. Storia di un visionario. Laterza, Roma.

Kliment, J. (1942): „Dante a jeho politické vyznání.“ In O jediné vládě, A. Dante, Melantrich, Praha, 1942 s. 9-38.

Kusánský, M. (1963, 1964, 1965, 1968): „De concordantia catholica.“ In NCOO. G. Kallen, sv. XIV, díl 1-4, Hamburg.

Maier, H. (1995): Politische Religionen: die totalitären Regime und das Christentum. Freiburg i.B.; český překlad K. Osolsobě, Politická náboženství: totalitární režimy a křest’anství, CDK, Brno, 1999.

Maritain, J. (1947): Traja reformátori. Spolok sv. Vojtecha, Trnava.

Marsilius z Padovy (1933): Defensor pacis. R. Scholz, Hannover.

Müller, I. (2011): „Dante, Ockham a Marsilius z Padovy.“ In Politické myšlení pozdního středověku a reformace, V. Herold, I. Müller \& A. Havlíček, Oikoymenh, Praha.

Passerin d'Entrèves, A. (1952): Dante as a Political Thinker. Clarendon Press, Oxford

Reynolds, B. (2006): Dante: the poet, the political thinker, the man. Counterpoint, London.

Salutati, C. (1985): De fato, fortuna et casu. C. Bianca, Firenze.

Welsch, W. (1988): Postmoderne - Pluralität als ethischer und politischer Wert. Bachem, Köln. 